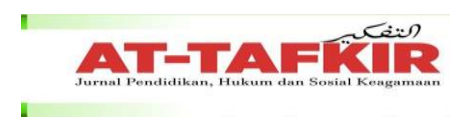

VOLUME 14 NOMOR 1 TAHUN 2021

P-ISSN : 1979-9357

E-ISSN : 2620-5858

\title{
Memahami Kembali Konsep Khiläfah dalam Sejarah Global
}

\author{
Kamaruzzaman Bustamam-Ahmad ${ }^{1}$, Fitri Zulfidar ${ }^{2}$ \\ Universitas Islam Negeri (UIN) Ar-Raniry, Darussalam, Banda Aceh ${ }^{1,}$ \\ Sekolah Tinggi Ilmu Sosial dan Ilmu Politik (STISIP) Al-Washliyah, Banda Aceh ${ }^{2}$ \\ kba140704@gmail.com, fitrizulfidar8@gmail.com
}

\begin{abstract}
This article examines the positioning of the concept of khilāfah in the context of global history. It must be admitted that this concept received a negative response from various groups, especially scholars and governments, which did not allow the power of Islam to emerge ideologically on the global stage. Therefore, various results of geopolitical analysis always assume that the concept of khiläfah is a concept that has a negative impact on the global order. However, as explained in this article, the concept of khilaffah has a very strong theological dimension in Islamic teachings. Therefore, the more it is shunned from being used as an Islamic political force, the stronger the desire of some Muslims to use this concept as an argument and pretext in their system of struggle. Through a bibliographic survey, this article finds that the problem of war or violence in the name of religion is not only triggered by the concept of khiläfah but there are other problems that arise socio-historically and socio-politically, in Muslim countries, where interests Western countries, also play a significant role geopolitically and geo-strategic, in the contestation.
\end{abstract}

Keywords: Khilāfah; Political Islam; Geo Politic; Terorrism; Global History

Abstrak: Artikel ini menelaah tentang pemosisian konsep khiläfah dalam konteks sejarah global. Harus diakui bahwa konsep ini mendapat respon yang tidak positif dari berbagai kelompok, terutama para sarjana dan pemerintah, yang tidak memberikan peluang kekuatan Islam secara ideologis muncul dalam pentas global. Karena itu, berbagai hasil analisa geo-politik selalu menganggap bahwa konsep khiläfah adalah suatu konsep yang membawa dampak buruk bagi tatanan global. Kendati demikian, sebagaimana dijelaskan dalam artikel ini, konsep khiläfah memiliki dimensi teologis yang amat kuat dalam ajaran Islam. Karena itu, semakin dijauhi untuk digunakan sebagai kekuatan politik Islam, semakin kuat keinginan sebagian Muslim untuk menggunakan konsep ini, sebagai dalil dan dalih dalam sistem perjuangannya. Melalui survey bibliografis, artikel ini mendapati bahwa persoalan perang atau kekerasan atas nama agama, bukan hanya dipicu oleh konsep khiläfah ini, melainkan ada persoalan-persoalan lain yang muncul secara sosio-historis dan sosio-politik, di negara-negara Muslim, di mana kepentingan negara-negara Barat, juga memainkan peran yang cukup signifikan secara geo politik dan geo strategis, di dalam kontestasi tersebut.

Kata Kunci: Khilāfah; politik Islam; geo politik; terorisme; sejarah global

\section{Pendahuluan}

Artikel ini akan menguraikan tentang konsep khiläfah. Bagaimana konsep tersebut digunakan di dalam lintasan sejarah ummat Islam. Tujuan utama studi ini adalah ingin menunjukkan bagaimana penggunaan istilah khiläfah dan khaliffah dalam konteks sejarah global. Diharapkan penjelasan telaah ini akan memberikan narasi maknawi tentang konsep-konsep tersebut. Sejauh ini, penggunaan beberapa istilah dari bahasa Arab cenderung dilebarkan pada

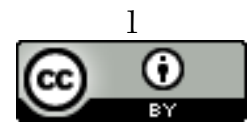

This work is licensed under a Creative Commons Attribution 4.0 International License 


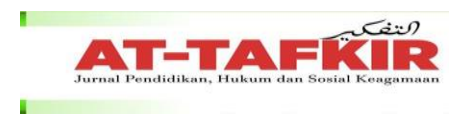

VOLUME 14 NOMOR 1 TAHUN 2021

P-ISSN : 1979-9357

E-ISSN : 2620-5858

kondisi sosio-kultural dan sosio-historis Muslim. Seperti istilah khiläfah yang pada awalnya dimaknai sebagai bagian dari istilah khaliffah yang berarti pengganti, sudah begitu menakutkan, jika dipakai kembali oleh ummat Islam dewasa ini. Hal ini disebabkan pengalaman sosio-kultural dan sosio-historis dalam kedua konsep ini jauh dari keinginan istilah-istilah yang dimunculkan di Barat. Istilah khiläfah yang berarti pemerintahan sepertinya tidak sepadan dengan konsep governance dalam bahasa Inggris. Karena di dalam konsep khiläfah terdapat nilai-nilai dari fungsi kemanusiaan di muka bumi sebagai khaliffah. Sementara istilah governance sama sekali tidak memiliki spirit seperti konsep khaliffah.

Salah satu istilah yang paling sering mendapat perhatian dunia dalam abad ke-2l ini adalah konsep khiläfah. Di Indonesia, istilah ini begitu menakutkan, karena dipandang akan mengancam ideologi negara. Di pentas global, konsep khiläfah merupakan konsep yang harus dicermati secara hati-hati, karena dipandang akan mengancam tatanan global. Harus diakui bahwa tidak ada istilah lain yang begitu menakutkan di dunia ini, selain konsep khilāfah. Pada saat yang sama, muncul juga istilah yang begitu disukai oleh masyarakat dunia yaitu pemerintahan global (global governance). Istilah global menjadi begitu banyak digunakan dalam dua atau dekade terakhir, seperti globalization dan global citizen (Al Gore 2013). Dalam penggunaan istilah yang mengglobal ini, istilah khiläfah selalu dihindari untuk dicari akarnya, karena mengacu pada pemerintahan Islam. Ada yang mengatakan bahwa khiläfah merupakan "bagian dari konservatisme baru" (Al Makin 2016:317).

Namun, dalam buku Masa Depan Dunia, diajukan tesis bahwa Amerika Serikat telah membangun suatu sistem khiläfah modern yang dikenal dengan konsep al-khiläfah al-amerikiy (Bustamam-Ahmad 2017b). Pada prinsipnya konsep khiläfah merupakan hampir mirip dengan konsep pemerintahan global. George Friedman menyebutkan suatu istilah bagi Amerika Serikat sebagai the unintended empire (kerajaan yang tidak diinginkan). Maksudnya, apapun yang dicapai Amerika Serikat hari ini telah mendudukkannya sebagai kerajaan. Friedman menjelaskan Kerajaan Amerika sebagai berikut:

The American president's unique status and influence are not derived from conquest, design, or divine ordination but ipso facto are the result of the United States being the only global military power in the world. The U.S. economy is also more than three times the size of the next largest sovereign economy. These realities give the United States power that disproportionate to its population, to its size, or, for that matter, to what might consider just or prudent. But the United States did intend to become empire. This unintentional arrangement was a consequnce of events, few of them under American control (Friedman 2012:14).

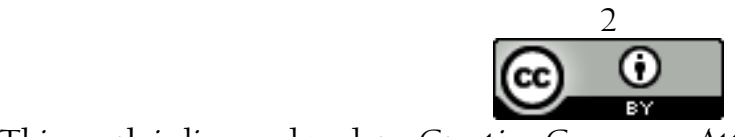

This work is licensed under a Creative Commons Attribution 4.0 International License 


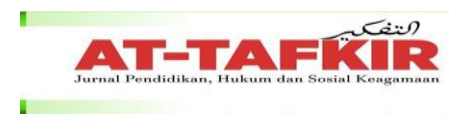

VOLUME 14 NOMOR 1 TAHUN 2021

P-ISSN : 1979-9357

E-ISSN : 2620-5858

Konsep yang ditawarkan oleh Friedman di atas memang menarik untuk ditelaah lebih lanjut. Karena dia mengajukan konsep 'ketidaksengajaan' (unintentional) Amerika Serikat menjadi suatu kerajaan yang mengontrol hampir seluruh dunia.

Dalam jangkaan masa depan, juga diprediksi bahwa ada skenario khilāfah baru (a new challiphate). Dimana akarnya dimulai dari identitas religi yang akan menghantam nilai-nilai dan norma-norma Barat yang sudah menjadi fondasi sistem global saat ini (National Intelligence Council 2004:16). Model skenario ini tentu bersamaan dengan skenario Pax Americana yang menginginkan Amerika Serikat sebagai satu-satu negara yang mengontrol tatanan global (global order). Keadaan masa depan yang diprediksi tersebut tentu saja menjadi begitu penting untuk dikaji atau ditelaah secara mendalam. Sebab, sebagai uninteded empire Amerika Serikat masih menjadikan konsep khilāfah, satu satunya konsep dari warisan sejarah peradaban Muslim, sebagai sesuatu yang amat perlu diwaspadai di masa yang akan datang.

Ketika artikel ini ditulis, isu khiläfah menjadi konsep yang ada dimana-mana dan begitu menakutkan, seperti ISIS mengusung isu khiläfah. Di samping itu, di Indonesia HTI dan FPI juga dibekukan, karena membawa isu khiläfah dalam perjuangan mereka yang dipandang mengancam keamanan dan pertahanan negara. Bahkan, di beberapa provinsi di Indonesia, sudah ada tokohtokoh yang mendirikan Khiläfah Muslim sebagai wujud kebangkitan Islam. Gerakan-gerakan Islam yang bersifat transnasional pun tidak ketinggalan menjalankan misi khiläfah, kendati tidak mengatakan bahwa mereka mendirikan khiläfah (Al Makin 2016:317). Salah satu gerakan Islam yang juga menggunakan istilah global adalah Global Ikhwan yang berevolusi dari nama Rufaqa, dimana sebelumnya dikenal sebagai Darul Arqam (Abdul Hamid 2005). Di Asia Tenggara, harapan atau keinginan untuk mendirikan khiläfah telah juga dipraktikkan upayanya oleh jaringan yang disinyalir sebagai gerakan terorisme atau radikalisme (Hendropriyono 2009) (Ali 2014) (Purwawidada 2014) (Basyir 2016). Pada prinsinya, imajinasi tentang khiläfah telah bermunculan di hampir seluruh penjuru dunia dalam jiwa dan pikiran ummat Islam, tidak terkecuali di Indonesia.

\section{Varian Makna Khilä fah}

Salah satu konsep yang paling dikhawatirkan sebagai turunan dalam kajian khiläfah adalah negara Islam (Islamic State). Dalam studi negara Islam, telah ditemukan juga beberapa konsep negara atau tata cara bernegara seperti daulah, imāmah, hukümah, sulțān, dan juga istilah khilāfah sendiri (Bustamam-Ahmad 2001) (Belkeziz 2009). Masing-masing istilah tersebut telah dan sedang dipraktikkan oleh ummat Islam dalam lintasan sejarah politik Islam. Praktik tersebut pada gilirannya menghadang konsep negara-bangsa (nation state), yang ditemukan di kawasan Barat (Cottam dan Cottam 2001). Adapun konsep-konsep yang diusung oleh konsep negara-bangsa

This work is licensed under a Creative Commons Attribution 4.0 International License 


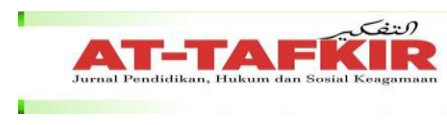

VOLUME 14 NOMOR 1 TAHUN 2021

P-ISSN : 1979-9357

E-ISSN : 2620-5858

inilah yang kemudian diperhadapkan dengan konsep di dalam pemikiran politik Islam, terutama dalam masalah kenegaraan. Berbagai konsep yang terdapat di dalam Islam harus diselaraskan dengan apapun yang ditemukan di kalangan para pemikir di Barat. Begitu banyak literatur yang mencoba menjelaskan konsep-konsep tersebut, hingga kemudian ada kesimpulan bahwa apapun yang ditemukan dalam Islam hanya dua pilihan yaitu compatible atau tidak compatible (Hallaq 2013) (Roy 1996) (Roy 2004).

Sejauh ini, karya-karya tentang gerakan Islam sangat banyak sekali ditulis oleh para sarjana. Dalam memahami karya-karya tersebut tentu saja menggiring pada telaah demi telaah secara konseptual. Karena hampir semua studi tentang gerakan Islam selalu dimulai dari suatu konsep yang dihasilkan oleh para sarjana, terutama dari Barat. Untuk itu, narasi sosio-historis mengenai perjalanan konsep akan disajikan dalam studi ini, supaya pembaca mendapatkan potret bagaimana konsep-konsep dari Barat dipasang di dalam memahami gerakan Islam. Walaupun tidak sedikit pula istilah-istilah dari Islam telah digunakan dalam dunia ilmu pengetahuan di Barat.

Manusia sebagai khalifah Allah di muka bumi merupakan pembedaan manusia dengan semua makhluk-makhluk lain ciptaan-Nya. Dawam Rahardjo dalam Ensiklopedi Al-Qur'an memberikan penjelasan konsep khilāfah dan khaliffah dalam al-Qur'an. Dalam al-Qur'an, akar kata tersebut yakni kh-l-fmuncul sebanyak 127 dengan 12 kata jadian (Rahardjo 1996:349) Lihat juga (Oliver-Dee 2009:14-16). Adapun kata jadiannya adalah khalafa (menggantikan), khalf (pergantian), khalīfah (wakil/pengganti), khulafä' (para pengganti), khawālïf (mereka yang ditinggal di belakang), khilāf (sesudah), khilfah (silih berganti), khālafa (menyalahi seseorang), akhlafa (gagal), takhallafa (tidak ikut menyertai), ikhtalafa (berlainan), istakhlafa (menunjuk sebagai pengganti) (Rahardjo 1996:347-48). Dari makna-makna tersebut menunjukkan bahwa kata kh-l-f merupakan sebuah proses atau sesuatu yang berubah menuju sesuatu yang lainnya.

Ketika Nabi Adam diciptakan oleh Allah sebagai khaliffah diberikan langsung ilmu dari Allah kepada nabi Adam. Allah ketika menciptakan alam semesta ini pun berdasarkan ilmu-Nya yang tidak terbatas. Proses inilah yang menyebabkan istilah wakil Allah di bumi tidak diterima oleh para makhluk langit. Artinya, drama konflik atas nama konsep khaliffah sudah terjadi, dimana Iblis berupaya untuk membuktikan sumpahnya untuk menggeser manusia dari fungsi kekhalifahannya. Apa yang menggeser ini pun telah Allah jamin bahwa manusia yang tidak akan mampu digeser-geser atau digoda oleh Iblis adalah mereka yang ikhlas di dalam ber-dīn kepada Allah. Di sini tampak bahwa fungsi kekhalifah adalah fugsi manusia di dalam melaksankan proses menuju dīn Allah (janji Allah) (Al-Attas 1995). Di sini terlihat bahwa kata khaliffah erat kaitannya dengan 'ilm dan dīn. Dengan bahasa lain, manusia diciptakan untuk menjadi khaliffah Allah melalui kekuatan 'ilmu supaya memahami tentang keberhutangannya dengan Allah (dīn Allah)..

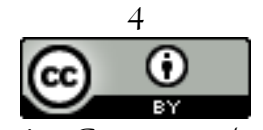

This work is licensed under a Creative Commons Attribution 4.0 International License 


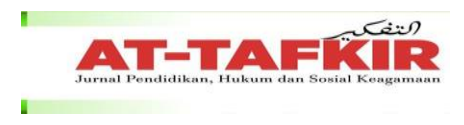

VOLUME 14 NOMOR I TAHUN 2021

P-ISSN : 1979-9357

E-ISSN : 2620-5858

Untuk tetap menjadikan semua pada poros-nya, maka Allah mengutus Nabi dan Rasul supaya manusia tetapi teringat akan fungsi kekhalifahannya di muka ini sebagai mukhlis. Inilah yang dipahami bahwa khalifah itu proses puncak manusia mencapai kesempurnaanya untuk mengakhiri dugaan demi dugaan Iblis supaya tidak mampu digelincirkan. Ketika manusia diutus ke muka bumi memiliki tugas sebagai wakil Allah, menghadapi kekuatan Iblis, dan mempersiapkan diri kembali kepada Allah. Makhluk-makhluk lainnya di muka bumi ini tidak memiliki tugas yang cukup berat ini, kecuali hanya manusia semata. Iblis mendapatkan restu dari Allah untuk menggelincirkan manusia. Malaikat hanya berbakti kepada Allah melalui fungsi kemalaikatannya. Makhluk lainnya ditundukkan supaya dapat menjadi objek dari kepentingan atau kebutuhan manusia di muka bumi ini. Di antara proses itulah, muncul manusia-manusia pilihan yang membawa risalah dari Allah. Mereka mendapat berbagai halangan tidak hanya dari kalangan Iblis, tetapi juga manusia yang sudah mengalami proses iblinisasi.

Di sini kemudian muncul konflik di antara sesama manusia. Ketika puncak kejahatan manusia tidak dapat ditolerir, maka muncullah respon alam sebagai bencana kepada manusia. Respon alam ini hanya untuk menundukkan manusia yang telah mengalami proses iblinisasi. Setelah sesuatu menjadi tenang, maka muncul lagi para pembawa risalah tauhid untuk menggulang pemahaman iblinisasi di kalangan manusia. Proses iblinisasi persis ketika Adam diciptakan yaitu enggan dan sombong. Dimana dua hal inilah yang mengantarkan manusia Iblis menjadi kafir. Istilah kafir bukanlah tidak mengerti akan risalah, melainkan enggan dan sombong terhadap apa yang Allah beritakan melalui manusia-manusia pilihan-Nya. Puncaknya adalah sama seperti pengalaman Iblis yang sombong di hadapan Allah, ketika diperintahkan untuk sujud kepada manusia.

Dari penjelasan di atas menunjukkan bahwa istilah khaliffah sangat erat kaitannya dengan manusia di dalam mengatur dirinya sebagai hamba Allah ('abd Alläh). Tidak ada kaitannya dengan pemerintahan atau persoalan politik. Allah menegaskan bahwa tugas manusia hanya untuk menghambakan diri kepada Allah. Di sini Allah menyebutkan tugas ini bersamaan dengan Jin.

Namun, dalam realitas politik global, setiap kemunculan negara atau gerakan yang mengusung ideologi yang hendak mendirikan khiläfah Islam selalu dicurigai atau bahkan dimusuhi dengan berbagai cara. Inilah yang menarik untuk diteliti lebih lanjut dengan mengapa istilah khiläfah begitu dicurigai atau dianggap sebagai ancaman global. Dapat dikatakan bahwa telaah ini berusaha untuk mengupas bagaimana istilah ini menjadi semacam "hantu global" (global ghost). Semakin sering negara-negara Muslim dihancurkan, semakin kuat pula dorongan dari ummat Islam untuk mendirikan khiläfah. Gerakan untuk mendirikan khiläfah muncul dimana-mana, kendati khalifah-nya hanya ada pada level nasional atau lokal. Dalam level internasional, kemunculan ISIS sendiri juga ingin mengkampanyekan tentang konsep negara Islam (Stern dan Berger 2015) (Chan 2015), yang juga merupakan bagian dari perjuangan untuk mendirikan

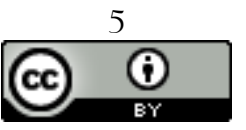

This work is licensed under a Creative Commons Attribution 4.0 International License 


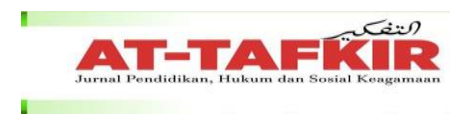

VOLUME 14 NOMOR 1 TAHUN 2021

P-ISSN : 1979-9357

E-ISSN : 2620-5858

khiläfah. Walaupun dalam dataran praktiknya, kelompok ISIS lebih banyak membunuh ummat Islam, ketimbang non-Muslim. Saat ini, demi memperjuangkan khiläfah para pembantai atau pembunuh langsung menghabisi saudara Muslim mereka sendiri, ketimbang kelompok nonMuslim. Pertanyaannya adalah mengapa istilah khiläfah ini telah memberikan virus pembantaian di antara sesama ummat Islam.

\section{Pengaruh Konteks Global terhadap Khiläfah}

Selanjutnya, dalam bagian ini dijelaskan beberapa pandangan sarjana Barat mengenai apa yang terjadi saat ini di Dunia Muslim. George Friedman dalam The Next 100 Years, menuturkan sebagai berikut: "One thing the United States has indisputably done since 2001 is to create chaos in the Islam world, generating animosity toward America - perhaps terrorists who will attack in the future" (Friedman 2010:49). Lebih lanjut, Friedman juga menyimpulkan: "So long as the Muslims are fighting each other, the United States has won its war" (Friedman 2010:49). Ketika Uni Sovyet tumbang sebagai puncak Perang Dingin, perang terjadi di Timur Tengah, hingga menghancurkan hampir semua negaranegara di kawasan tersebut. Timur Tengah menjadi arena perang yang tidak pernah berkesudahan, hingga memunculkan Arab Spring pada tahun 2011. Sebagaimana dinyatakan oleh Friedman, ummat Islam saling berperang antara satu sama lain. Sampai di sini, Amerika Serikat tetap menjadi negara stabil yang menjaga kestabilan global.

Ketika kajian ini disusun, perang terus terjadi di Timur Tengah, dimana Amerika Serikat menjadi aktor utama. Persis peristiwa ini terjadi pada saat Perang Dingin. Di tengah-tengah arena tersebut muncul kelompok yang mengusung isu pendirian khiläfah. Drama yang hampir mirip, kendati tidak dengan kekuatan fisik juga terjadi di Indonesia, dimana arena perang juga berlaku antara sesama ummat Islam, antara kelompok yang diklaim sebagai moderat dengan kelompok yang disinyalir radikal. Tentu saja, kelompok yang akan memenangkan arena perang di Indonesia, bukan dari kalangan Muslim juga, seperti pengalaman di Timur Tengah.

Keadaan di atas, persis seperti yang ditulis oleh Henry Kissinger dalam World Order, dimana dunia Islam dan Timur Tengah disebut sebagai "a World of Disorder" (Kissinger 2014:96). Dalam bahasa sederhana, istilah tersebut dapat diartikan sebagai dunia tanpa tatanan atau tidak punya orientasi. Gambaran ini menyiratkan bahwa saat ini, Islam memiliki masalah yang amat parah dan perih (Lewis 2002). Pada awalnya, Islam menurut Kissinger pernah sebagai "a religion, a multuethnic superstate, and a new world order" (Kissinger 2014:99). Namun, ketika Kristen mengambil peran sebagai tatanan baru dunia, Islam menjadi tergantikan secara paksa dalam skala global. Kondisi ini secara simultan hancur saat kejatuhan Khilafah Turki Utsmani pada 1924 (Oliver-Dee 2009). Sejak saat itu, khiläfah Islam menjadi sejarah ummat Islam semata. Berbagai gerakan muncul dalam

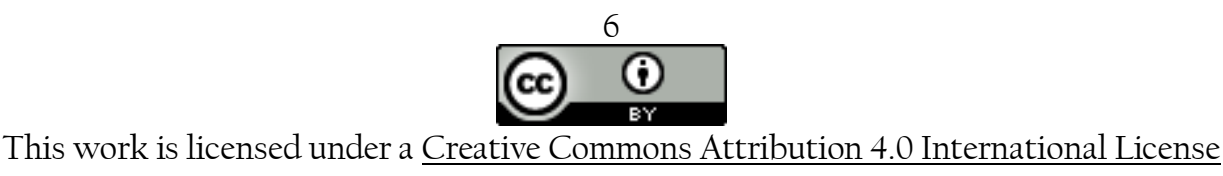




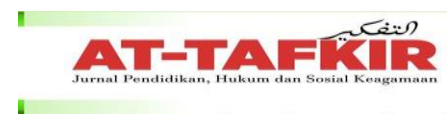

VOLUME 14 NOMOR 1 TAHUN 2021

P-ISSN : 1979-9357

E-ISSN : 2620-5858

Islam untuk berusaha mendirikan Negara Islam (Islamic State) atau Khiläfah Islam (Esposito 1984) (Ismail 2003).

Kondisi sebagai a world of disorder memang tidak kalah perihnya, ketika para sarjana mengatakan bahwa Islam dan ummat Islam merupakan masalah dunia saat ini. Persoalan ini termasuk dalam 7 kontradiksi global, yang disampaikan oleh Kishore Mahbubani dalam The Great Convergence, yaitu: kepentingan-kepentingan global versus kepentingan-kepentingan nasional; Barat versus selain Barat; kekuatan utama dunia versus kekuatan utama dunia yang sedang bangkit; ekspansi Cina versus penyusutan dunia; Islam versus Barat; lingkungan global versus konsumer global; pemerintahan versus organisasi non-pemerintah (Mahbuni 2013:118-37). Adapun tentang Barat versus Islam, Mahbubani menandaskan ada beberapa hal sebagai penyebab salah paham, yaitu- (Mahbuni 2013:132-33): Pertama, persoalan sejarah. Masing-masing pihak memori kebudayaan tentang Perang Salib. Kedua, persoalan religi. Ummat Kristen, dalam beberapa hal tertentu, semakin sekular, sementara ummat Islam semakin religius. Ketiga, masalah psikologi. Masing-masing kelompok memiliki perasaan sebagai korban. Ummat Islam, lanjut Mahbubani, memiliki perasaan bahwa mereka telah dikolonialisasi selama hampir 2 abad sampai 1940-an, mulai dari Maroko di Barat, sampai Indonesia di Timur. Tidak hanya itu, setelah masa de-kolonialisasi, kekuatan Barat masih menginjak-injak semua kepentingan ummat Islam (Mahbuni 2013:133) Lihat juga- (Lewis 1993).

Persoalan yang disampaikan di atas agaknya mewarisi sistem kemudi sejarah ummat Islam dewasa ini. Mereka berada dalam bayangan dan situasi bahwa "Western power trampled over all their interest," dalam bahasa Mahbubani. Proses diinjak-injak (trampled) inilah yang sedang dialami oleh ummat Islam di seluruh dunia, bahwa Muslim memiliki sejarah kedigdayaan dan kemudian, namun sekarang dalam mencari format baru sistem pemerintahan global, mereka sama sekali tidak diberikan kesempatan, kecuali mau bersetuju dengan nilai-nilai dan norma yang dihasilkan oleh para pemikir Barat (Ansary 2009) (Fukuyama 2012:Bab 15). Proses pencarian ini persis pada era modern, dimana ummat Islam selalu menjadi objek dari percaturan global. Sejak kejatuhan wilayah Timur Tengah ke dalam proses kolonialisasi oleh bangsa-bangsa Eropa, ummat Islam selalu mencoba bangkit melalui konsep-konsep dari warisan sejarah Islam untuk dapat duduk sejajar dalam era modern.

Salah satu contoh respon kejatuhan khiläfah adalah Mustafa Kemal yang dikenal sebagai Ataturk - Bapak Turki, yang mendeklarasikan Turki sebagai negara sekular dalam bentuk negarabangsa pada tahun 1923 (Lewis 1952). Di sini Kemal mengambil nilai-nilai dan konsep dari Barat sebagai basis ideologi, yaitu nasionalisme, sekularisme, reformisme, statisme, populisme, dan republikanisme (Ansary 2009:302). Konsep-konsep inilah, terutama empat yang pertama, yang kemudian tersebar ke seluruh Dunia Islam setelah Perang Dunia I (Ansary 2009:302).

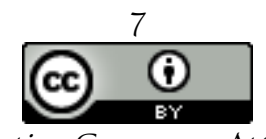

This work is licensed under a Creative Commons Attribution 4.0 International License 


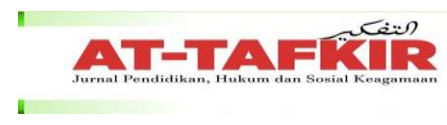

VOLUME 14 NOMOR 1 TAHUN 2021

P-ISSN : 1979-9357

E-ISSN : $2620-5858$

Pengaruhnya juga sampai ke Indonesia, dimana kemudian disambut oleh Soekarno, sebagai Presiden Pertama Republik Indonesia (Al Makin 2016).

Karena itu, sejarah politik Islam mulai berpencar ke dalam berbagai aliran untuk merespon kejatuhan khilāfah. Pada saat yang sama, berbagai konsep dari pemikiran Barat mulai diinstalisasi ke dalam masyarakat Muslim. Pada era tersebut, perkembangan di dalam ilmu-ilmu sosial mulai bangkit, dimana musuh utamanya adalah Nazi di negara Jerman. Konteks sejarah ini memberikan kesempatan untuk kebangkitan Zionisme pada tahun 1890 dan berkembang menjadi protokol bagi ummat Yahudi di seluruh dunia. Pada tahun 1936, pusat Zionis ditetapkan di Yerussalem. Puncaknya, pada 14 Mei 1948, para Zionis mendeklarasian negara Islam. Tepatnya, pada era tersebut, Islam runtuh, Yahudi bangkit. Namun, sebelum era ini, pada abad ke-17 dan $18 \mathrm{M}$, telah muncul konsep Haskalah, yaitu era pencerahan Yahudi. Konsep ini digagas oleh Moses Mendelssohn (1729-1786). Oleh sebab itu, perpindahan Yahudi dan pencerahan yang didengungkan melalui konsep Haskalah telah menciptakan suatu kondisi dunia baru bagi komunitas Yahudi, tepat di negara-negara Eropa. Pengaruh Zionisme dalam kejatuhan khilāfah tidak dapat diabaikan sama sekali.

Jika dihitung tahun kejatuhan khiläfah yaitu pada 3 Maret 1924 M, maka pada tahun 2024, akan mencapai satu abad. Pada tahun 1948, negara Israel akan berusia satu abad pula. Sejak ISIS mendengunkan khiläfah pada tahun 2014, maka pada tahun dimana kejatuhan khiläfah berusia satu abad, dapat dipastikan bahwa dalam beberapa tahun kemudian, konsep ini akan banyak mewarnai konsep gerakan Islam di seluruh dunia. Dalam durasi satu abad inilah konflik dunia banyak diilhami oleh konsep khilāfah. Sejak tahun 1948, telah juga terjadi proses Yahudinasi tempat-tempat suci bagi ummat Islam (Bar t.t.:6) (Armstrong 2005). Negara Palestina menjadi the largest open air prison terbesar di dunia sampai saat ini. Sedangkan, secara keseluruhan, Timur Tengah menjadi the largest arena for war dalam abad ke-2l M.

Kondisi di atas tentu saja perlu dikupas secara mendalam untuk melihat arah masa depan dunia dalam konteks penegakan khiläfah saat ini, oleh beberapa organisasi atau gerakan Islam. Apakah masa depan ummat Islam sangat ditentukan dengan berdirinya kembali sistem khiläfah? Dalam teologi ummat Islam, kemunculan Imam Mahdi dan Nabi Isa. Sinyal kedatangan mereka untuk mengatakan bahwa kiamat akan datang dalam waktu dekat. Dalam rotasi peradaban dunia, kedatangan mereka memang tidak menyebutkan sosok yang pasti, melainkan hanya tandatandanya semata. Konteks Imam Mahdi dan perjuangan pendirian khiläfah menjadi penting, seiring dengan kemunculan gerakan Islam yang menginginkan kedua hal tersebut muncul, untuk menghadapi dominasi kekuatan non-Muslim di pentas dunia ini. Hanya saja, perlu ditelaah lebih dalam lagi tentang apakah kemunculan gaya perjuangan khiläfah saat ini adalah sinyal akan kedatangan Imam Mahdi. Di sini, konteks teologis-normatif dengan sosio-historis ummat Islam perlu dilihat secara seksama.

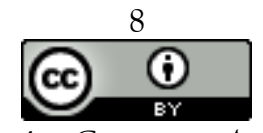

This work is licensed under a Creative Commons Attribution 4.0 International License 


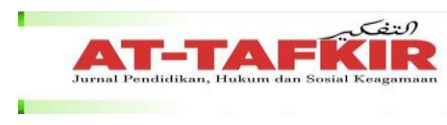

VOLUME 14 NOMOR 1 TAHUN 2021

P-ISSN : 1979-9357

E-ISSN : 2620-5858

Apabila diurut rotasi sejarah, maka pada tahun 2024, negara Amerika yang merdeka pada 4 Juli 1776, akan berusia 248 tahun. Negara ini akan berusia sekitar hampir dua abad setengah. Lebih lanjut, pada tahun 2076, Amerika Serikat akan berusia 300 tahun. Apa hubungannya dengan konteks khilāfah? Dalam beberapa skenario global Amerika Serikat, khilāfah juga mendapat hal yang begitu signifikan untuk dijadikan bahan pertimbangannya, mengenai sejarah masa depan. Dalam Mapping the Global Future, ditegaskan bahwa salah satu skenario dunia yang akan muncul adalah A New Caliphate, dimana dijelaskan sebagai berikut: “... provides an example of how a global movement fueled by radical religious identity politics could constitute a challenge to Western norms and values as the foundation of the global system" (National Intelligence Council 2004:16). Kondisi ini diprediksi terjadi pada tahun 2020. Walaupun sekarang ini kondisi yang dijangka tersebut sudah terjadi. Pada waktu yang bersamaan, hampir semua titik kekuatan kekuatan Muslim di Timur Tengah sedang bergejolak, kecuali di dua tempat yaitu Arab Saudi dan Iran.

Kondisi ini juga terjadi di Asia Tenggara, dimana gerakan Islam yang membawa isu khilāfah juga sedang mendapatkan sorotan, terlebih saat artikel ini ditulis, di Marawi sedang terjadi pergolakan antara ISIS dengan pemerintah Filipina. Di Indonesia, persoalan terorisme dan ormas yang membawa isu khilāfah juga mendapatkan sorotan dari pemerintah. Salah satu gerakan Islam yang dibekukan karena mengusung khilāfah adalah Hizbut Tahrir Indonesia. Dengan kata lain, isu khiläfah menjadi momok yang menakutkan, seperti yang ditakuti oleh pemerintah Amerika Serikat dalam Mapping the Global Future. Kondisi fiksional yang digambarkan surat Said Muhammad bin Ladin kepada salah seorang saudara yang tertanggal 3 Juni 2020 (National Intelligence Council 2004:85-91). Dalam surat fiksi tersebut dimulai dengan keinginan untuk mendirikan sistem khalifah yang pernah dipraktikkan pada era sahabat Rasul.

\section{Dimensi Pemosisian Khilā fah}

Konsep ini telah lahir semenjak Islam hadir di muka bumi ini, khususnya saat empat sahabat Rasul SAW menjadi pemimpin setelah rasul. Bahkan, ketika manusia pertama kali diciptakan oleh Allah, kata khalifah telah membuat masyarakat langit begitu tidak menghendaki manusia mengembang tugas sebagai khalifah di muka bumi ini. Golongan Iblis tidak rela manusia menjadi khalifah Allah. Karena itu, konsep khiläfah telah menjadi akar permasalahan, tidak hanya di bumi, tetapi juga di langit. Bahkan Iblis berani diusir dari Surga demi untuk menggoda manusia di bumi, karena Allah telah menetapkan manusia sebagai khalifah-Nya.

Tentu saja, persoalan di atas menjadi akar masalah tentang fungsi kemanusiaan di bumi ini. Sebab, di satu sisi ada amanah yang diemban sebagai Khalifah Allah, di sisi lain, ummat Islam juga menghadapi masalah bertubi-tubi ketika memperjuangkan khiläfah. Persoalan khalifah dan khilāfah menjadi persoalan utama bagi manusia yang memiliki hubungan dengan Sang Pencipta

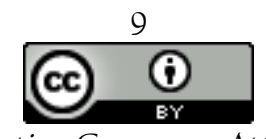

This work is licensed under a Creative Commons Attribution 4.0 International License 


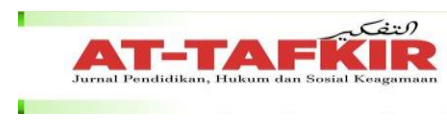

VOLUME 14 NOMOR 1 TAHUN 2021

P-ISSN : 1979-9357

E-ISSN : 2620-5858

(Madjid 1999). Saat ini, persoalan ini juga berlaku di bumi, mana kala ummat Islam ingin mengembalikan konsep sebagai basis pemerintahan Islam. Hal ini belum lagi pengalaman ummat Islam di dalam mempraktikkan pemerintahannya dalam lintasan sejarah dunia, mulai semenjak era 4 sahabat Rasulullah SAW hingga menjelang kejatuhan khiläfah pada abad ke-19. Sejarah ummat Islam hampir 13 abad lebih merupakan catatan tersendiri, ketika ummat Islam menjalankan misi kekhilāfahan dalam bentuk tidak hanya pemerintahan, tetapi juga bagian dari sejarah politik Islam.

Tiga hal tersebut merupakan titik utama mengapa ini ingin menyajikan konsep khiläfah dari berbagai dimensi. Sebab, pemahaman Islam hadir juga melalui berbagai dimensi pengetahuan manusia. Salah satu dimensi yang paling sering dikupas adalah aspek pemikiran politik Islam. Dimensi ini juga sangat terkait dengan dimensi-dimensi lainnya seperti hukum Islam, tasawuf, dan kalam. Karena itu, kajian politik di dalam Islam juga menyangkut aspek-aspek hukum, spiritual, dan teologi. Khazanah pemikiran Islam yang begitu luas membentang selama hampir 13 abad lebih tentu saja memberikan sekian pemahaman tentang bagaimana seharusnya pemerintahan dijalankan. Kontak Islam dengan Barat, terutama Eropa juga memberikan pengaruh bagi citra pemahaman Islam di kalangan para sarjana Muslim. Kondisi ini diperuncing dengan kehadiran berbagai aliran pemikiran dalam wilayah hukum Islam, kalam, dan juga sufisme, dimana terkadang dibangun atas kepentingan rezim penguasa. Akibatnya, studi tentang khiläfah pada gilirannya juga merupakan kajian tentang sejarah politik Islam, baik di dalam maupun ketika terjadi kontak dengan Barat.

Dimensi kemanusiaan (insāniyyah) juga didapati dalam kajian khilāfah. Setiap manusia mengembang misi kekhalifahan dari Allah. Setiap pemimpin diminta pertanggungan jawaban. Setiap manusia dilahirkan secara fitrah. Setiap manusia dituntut untuk taat kepada Allah, Rasulullah, dan pemimpin. Aturan-aturan dari Allah harus ditegakkan. Ibn Khaldun (2001:337) mengatakan bahwa: "Kekhalifahan ...pada hakikatnya merupakan pengganti atau wakil Allah di dalam menjaga agama dan kehidupan manusia." Dua aspek inilah yang sering dikupas dalam kajian pemerintahan Islam, sebagaimana terlihat dalam karya al-Mawardī dan Abī Ya'lā. Konsep imärah dan imämah kerap muncul di dalam tata kelola pemerintahan Islam. Proses mendetailkan tata kelola pemerintahan Islam ini kadang juga dimulai dari bagaimana bentuk kemanusiaan yang diinginkan, baik sebagai pemimpin maupun sebagai yang dipimpin.

Lebih lanjut, konteks global dan nasional yang terjadi di Indonesia juga memberikan alasan kuat mengapa pengkajian terhadap konsep khiläfah perlu disajikan secara komprehensif. Saat ini, kemunculan gerakan khiläfah, baik yang membawa panji-panji khiläfah, maupun hanya sebatas pada dataran konsep spiritualisme Islam telah membawa dampak serius terhadap keberadaan Muslim dan Islam itu sendiri. Oleh sebab itu, perlu studi yang menyajikan atau mendudukkan konsep khiläfah pada posisi awal di dalam ajaran Islam. Mengapa kemudian, bagi

This work is licensed under a Creative Commons Attribution 4.0 International License 


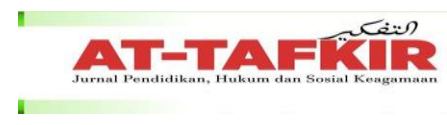

VOLUME 14 NOMOR 1 TAHUN 2021

P-ISSN : 1979-9357

E-ISSN : 2620-5858

yang mengusung konsep ini harus membunuh orang non-Muslim atau sesama Muslim sendiri. Apakah ini terkait dengan kontinuitas sejarah konflik internal ummat Islam yang terjadi ribuan tahun lalu mengalami puncak dalam abad sekarang? Atau, apakah ini terkait dengan usaha nonMuslim supaya Islam sebagai kekuatan ideologi tidak lagi dapat berperan dalam konteks global? Tentu tidak mudah menemukan jawaban yang tepat untuk kedua pertanyaan tersebut. Namun, paling tidak kita dapat mengajukan pertanyaan yang tepat untuk mencari jawaban yang masih memerlukan pendalaman secara substantif.

Studi ini pada prinsipnya ingin menjawab dari beberapa pertanyaan dan pernyataan dalam tiga bagian di atas. Pengalaman penulis menulis topik ini bermula saat menyelesaikan skripsi tentang hubungan Islam dan negara (Bustamam-Ahmad 2001). Lantas, dalam pengkajian master, pengkaji menulis tentang Islam Politik di Indonesia (Bustamam-Ahmad 2013). Sementara saat doktoral, dikaji tentang Gerakan Islam di Asia Tenggara (Bustamam-Ahmad 2015). Karena itu, data untuk pengkajian tentang politik Islam yang menyangkaut kenegaraan, telah dipersiapkan selama hampir satu dekade lebih. Hanya saja, penuis mulai fokus pada studi ini, setelah menyelesaikan proyek penulisan tentang Studi Aceh (Acehnologi) (Bustamam-Ahmad 2017a). Dalam pengkajian tersebut, penulis telah menghasilkan karya tentang radikalisme dan terorisme di Indonesia. Sehingga, salah satu ujung dari karya-karya tersebut perlu pengkajian secara akademik tentang tentang konsep khiläfah.

\section{Dari Khilä fah ke Terorisme}

Setelah kita memahami tentang konsep khilāfah dan khalifah, maka bagian ini ingin membedah bagaimana kemudian konsep ini dikaitkan dengan persoalan terorisme. Dewasa ini, upaya mengaitkan konsep khiläfah dengan terorisme kerap terjadi di seluruh penjuru dunia. Bahkan, khilāfah dipandang sebagai sebuah gerakan yang amat menakutkan, karena dikaitkan dengan aksi-aksi radikalisme dan terorisme, tidak terkecuali di Indonesia. Salah satu konsep yang sering dikaitkan dengan keadaan tersebut adalah melalui konsep jihäd. Salah satu argumen yang hendak disampaikan dalam bab ini adalah bahwa di antara konsep khiläfah dan jihād sama sekali tidak ada hubungannya dengan radikalisme dan terorisme, melainkan ada situasi yang mendukung aksi-aksi terorisme yang dipicu oleh keinginan untuk mencapai khiläfah. Salah satu pemicu utama dalam aksi-aksi terorisme itu adalah terletak pada pemahaman tentang penerapan dari ideologi yang berasal dari Islam, dimana sangat dikhawatirkan menjadi suatu pemicu ketidakstablian global.

Ketika Islam hadir pada masa Rasulullah, tidak ada apapun stigma yang muncul, kecuali membelah dunia Arab, karena saat itu, Nasrani dan Yahudi yang muncul duluan sebelum Islam. Ada yang menyebutkan bahwa: "Without Islam, Eastern Orthodox Christianity would likely have remained the dominant faith of the Middle East down to today, with possible exception of Zoroastrianism in Iran " (Fuller

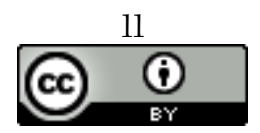

This work is licensed under a Creative Commons Attribution 4.0 International License 


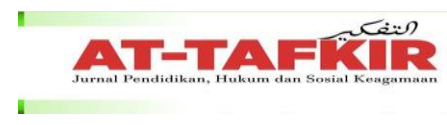

VOLUME 14 NOMOR I TAHUN 2021

P-ISSN : 1979-9357

E-ISSN : 2620-5858

2010:24). Nusantara juga menjadi negeri yang menjadi penganut animisme atau Hindu-Buddha, jika Islam tidak sampai ke negeri ini. Terlepas dimana terlebih dahulu Islam pertama kali bertapak di Nusantara. Iran tanpa Islam akan terus menjadi negeri penganut Zoroaster. India dengan penganut Hindu. Demikian pula, Cina dengan agama nenek moyang mereka. Barat (Eropa), tentu akan menjadi negeri tribal, dimana kemudian Kristen-Barat menyisir kawasan ini. Jadi, tidak akan ada ISIS atau apapun gerakan yang memperjuangkan Islam seperti yang terlihat hari ini. Iran yang kemudian menjadi negeri Muslim, harus menerima dampak hingga hari ini, karena telah menyalin diri mereka ke dalam Islam.

Dalam era kecanggihan media sosial dan kebangkitan netizen, informasi tentang tentang pergolakan di kawasan Muslim, terutama yang menyangkut khilāfah, jihād, dan gerakan Islam selalu membombardir media sosial. Informasi yang berterbangan di alam maya menuntut kita kemudian untuk berpikir jernih. Ada apa sebenarnya? Atau, sebenarnya ada apa? Atau bahkan, apa ada sebenarnya? Jika dikaitkan dengan kemunculan ISIS bisa juga dilekatkan dengan ada apa sebenarnya dengan ISIS? Sebenarnya ada apa dengan ISIS? Dan, apa ada sebenarnya ISIS? Demikian pula dengan kemunculan Wahabi? Syi‘ah? Sunni? Istilah khilāfah muncul dari Islam yang kemudian menjadi konsep yang memberikan inspirasi ummat-nya untuk ber-jihād.

Menjawab ketiga pertanyaan di atas, terkait dengan ISIS tentu akan memiliki beberapa jawaban yang sama sekali tidak berhubungan. Terlepas ISIS diberikan kepanjangan sebagai Islamic State of Iraq and Syria, namun dalam mitologi iteratur kuno Mesir, Isis merupakan pasangan dari Osiris. Sebenarnya, mereka merupakan anak dari Dewa Langit yang terdiri dari Osiris, Isis, Set, dan Nepthys. Osiris merupakan anak tertua yang menikah dengan Isis. Akan tetapi Set merasa cemburu akan Osiris, hingga dia kemudian membunuh Osiris. Isis, yang memiliki kekuatan magik yang amat luar biasa, lantas berusah untuk membangkitkan kembali Osiris. Sehingga mereka berkumpul lagi dan kemudian memiliki putra, yang bernama Horus (Black 2013:28-33). Kisah mitologi Mesir ini memang tidak ada kaitannya dengan nama ISIS yang lahir pada tahun 2014. Secara metafisika, konflik antara para Dewa di dalam mitologi Mesir, persis yang terjadi saat ini di Timur Tengah, ISIS merupakan "dewa” yang memiliki kekuatan yang amat luar biasa untuk membalas dendam menciptakan huru hara di seluruh dunia.

Keadaan ini dikenal dengan istilah Arab Spring, yang dimulai pada 17 Desember 2010 di Tunisia. Di Mesir telah terjadi Revolusi pada 25 Januari 201l. Pada tahun yang 2011, tanggal 2 Mei, Osama bin Laden juga tewas di Abbottabad, Pakistan. Setelah itu, pada 20 Oktober 201l, Muammar Gaddafi juga tewas di Libya. Sebelum itu, pada 15 Maret 2011 juga terjadi perang sipil di Suriah. Setelah kelahiran ISIS pada tahun 2014, konflik berlanjut di Yaman yang dimulai pada 22 Maret 2015. Kondisi pada tahun-tahun tersebut telah berdampak di semua negara-negara Arab yaitu Bahrain, Kuwait, Lebanon, Oman, Maroko, Yordan, Arab Saudi, Mauritania. Begitulah keadaan Timur Tengah dewasa ini, yang kemudian menampakkan ISIS sebagai salah satu gerakan

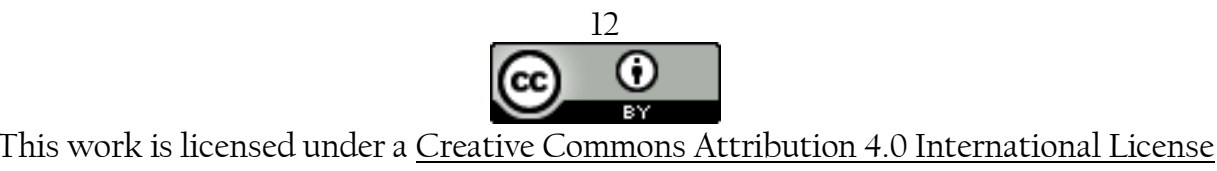




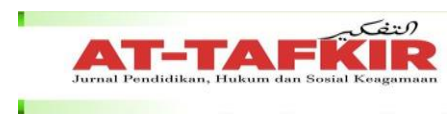

VOLUME 14 NOMOR 1 TAHUN 2021

P-ISSN : 1979-9357

E-ISSN : 2620-5858

Islam yang tidak memiliki basis teritori negara menyebar ke seluruh dunia. Di ujung kondisi ini, muncul istilah khilāfah atau Islamic state (negara Islam).

Sebelum itu, gerakan yang memiliki dampak yang amat luar biasa adalah al-Qaeda dibawah pimpinan Osama bin Laden. Puncak peristiwanya adalah ketika terjadi penabrakan pesawat yang disinyalir oleh al-Qaeda pada tanggal 11 September 2001. Setelah itu, muncul slogan War on Terror dibawah komando Amerika Serikat dan sekutunya. Setelah itu, respon yang muncul adalah penyerangan Taliban yang disinyalir sebagai bagian dari al-Qaeda. Peristiwa ini dilakukan pada 7 Oktober 2001. Pada tahun 2003, tepatnya 20 Maret digelar Perang di Irak yang berakhir pada tahun 18 Desember 201l. Saddam Hussein ditangkap dan dieksekusi pada 30 Desember 2006. Sebelumnya, Irak juga menjadi target pada tahun 1990, ketika terjadi Perang Teluk. Hal ini disebabkan karena Irak menginvansi Kuwait. Hanya saja, saat itu, Saddam Hussein tidak dapat ditundukkan sebagaimana pada tahun 2003. Michael Doran mengatakan bahwa kondisi Timur Tengah pada era ini sebagai: “... this kind of military disaster occurs with relative frequency in the Middle East as conquence of the complex balance of power in the region. Fanaticism, therefore, played no role in al Qaeda's miscalculation" (Doran 2002:177).

Jauh sebelum peristiwa di atas terjadi, juga telah berlaku Perang Irak dan Iran yang dimulai pada 22 September 1980 hingga 20 Agustus 1988. Sebelum tahun 1980 juga telah berlaku Revolusi Iran, dimana rezim sekular di negara tersebut diganti oleh para 'ulama melalui konsep wilayat al-faqīh. Jauh sebelum itu, juga terjadi konflik di Timur Tengah selepas perang dunia kedua, terdapat dua peristiwa penting yaitu kemerdekaan Israel pada tahun 1948 dan dimulai Perang Dingin, antara Uni Sovyet dan Amerika Serikat. Perang Dunia pertama menghasilkan PBB yang didirikan pada tahun 1945. Dalam Perang Dingin, konflik di Timur Tengah tidak pernah padam. Amerika Serikat mendanai sebuah proyek perang besar untuk menghadapi Uni Sovyet yang dikenal dengan istilah Arab-Afghan. Sovyet jatuh pada tahun 1991 dalam Perang Dingin beberapa negara Timur Tengah membantu upaya Amerika Serikat untuk menghabisi Sovyet, dengan dalih sebagai komunis.

Nestapa Timur Tengah memang bukanlah dimulai sejak tahun 2014, ketika ISIS menggelorakan Khiläfah. Ada peta perang di kawasan tersebut. Ada pemuaian ideologi di Jazirah Arab. Banyak tokoh pemikir yang menghiasi lembaran sejarahnya. Ada jutaan manusia yang telah gugur di dalam setiap konflik. Ratusan ribu manusia harus pindah tempat, mereka melintasi benua untuk bertahan hidup dan berketurunan. Banyak bangunan yang merupakan bukti kedigdayaan ummat Islam yang hancur. Agaknya telah begitu banyak studi dan kajian yang mengupas peristiwa-peristiwa penting di Timur Tengah. Karena itu, persoalan khilāfah, bukan persoalan terorisme, melainkan masalah ini adalah sebuah kontinuitas sejarah yang belum menemukan titik terang, bagi ummat Islam. Kultur perang memang sudah ada di dalam sejarah Timur Tengah.

13

This work is licensed under a Creative Commons Attribution 4.0 International License 


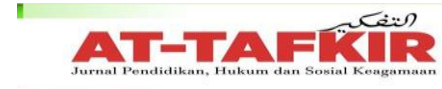

VOLUME 14 NOMOR 1 TAHUN 2021

P-ISSN : 1979-9357

E-ISSN : 2620-5858

Bronislaw Malinowski menyebutkan bahwa: "The problem of what war is a cultural phenomenon naturally falls into the constutuent issues of the biological determinants of war, its political effects, and its cultural contructiveness" (Malinowski 1941:523). Perang sebagai fenomena kebudayaan sesuatu yang tidak dapat dihindari sama sekali. Hampir tidak ada negara yang tidak memiliki sejarah perang. Setiap perang selalu memiliki penyebab di dalamnya. Berbagai istilah dilekatkan padanya. Kehancuran kekhalifahan Islam di Timur Tengah pun disebabkan oleh peperangan dan campur tangan bangsabangsa Eropa di dalamnya (Satia 2008) (Fisk 2006a). Bangsa-bangsa penjajah, selain mempersiapkan persenjataan, juga menyiapkan alasan-alasan akademis di belakangnya, sebelum perang dimulai. Alasan-alasan perang inilah yang terkadang dicari, dibingkai, diikat, lalu diletakkan sebagai suatu kekuatan untuk menggerakkan suatu kelompok untuk maju ke medan perang. Terkadang alasan-alasan tersebut dicari di dalam kitab suci, ambisi pribadi, dendam sejarah, dan perluasan wilayah kekuasaan. Sejarang perang adalah sejarah individu yang terlibat di dalam bagian dari peperangan itu sendiri. Ketika kekhalifahan Islam runtuh, tidak sedikit individu mencari alasan untuk membangkitkan kembali kekuatan Islam secara politik.

\section{Kesimpulan}

Dari beberapa uraian di atas, ada beberapa hal yang perlu digarisbawahi. Pertama, konsep khiläfah merupakan konsep yang paling mendapatkan perhatian di dalam pentas global. Konsep ini, pada hakikatnya memiliki nuasan teologis di dalam kajian Islam, namun memiliki dimensi teo-politis, jika dijadikan sebagai ideologi dalam kajian politik Islam. Kedua, kendati konsep khiläfah merupakan momok yang amat menakutkan, isu ini akan terus bergulir sepanjang masa, sebab persoalan kekhalifahan manusia merupakan perbincangan manusia sejak pertama kali diciptakan oleh Allah SWT. Ketiga, isu khilāfah yang sering mengundang sejumlah kekerasan atas nama agama, tampaknya tidak melulu disebabkan oleh konsep ini, melainkan ada sejumlah persoalan yang sudah membumi, di beberapa negara, khususnya negara Muslim, selama puluhan tahun, kemudian meledak menjadi masalah global, ketika dikaitkan dengan persoalan khilāfah.

\section{DAFTAR PUSTAKA}

Abdul Hamid, Ahmad Fauzi. 2005. "The Banning of Darul Arqam in Malaysia." Review of Indonesian and Malaysian Affairs 39(1):87-128.

Abi Ya'la. 1993. Al-Ahkām al-Sulțāniyyah. Beirut: Dar al-Fikr.

Al Gore. 2013. The Future. New York: WA Allen.

Al Makin. 2016. "Tanggalkan Khalifah di Bumi Ini: Membaca Narasi Sukarno tentang Sekularisme Turki." Al-Tahrir: Jurnal Pemikiran Islam 16(2):267-92.

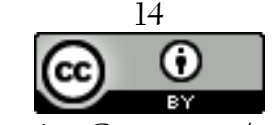

This work is licensed under a Creative Commons Attribution 4.0 International License 


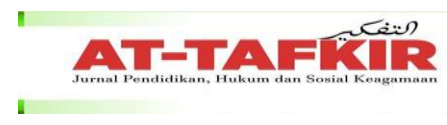

VOLUME 14 NOMOR I TAHUN 2021

P-ISSN : 1979-9357

E-ISSN : 2620-5858

Al-Attas, Syed Muhammad Naquib. 1995. Prolegomena to the Metaphysics of Islam: An Exposition of the Worldview of Islam. Kuala Lumpur: International Institute of Islamic Thought and Civilization (ISTAC).

Ali, As'ad Said. 2014. Al-Qaeda: Tinjauan Sosial Politik, Ideologi dan Sepak Terjangnya. Jakarta: LP3ES. Al-Mawardi, Abi al-Hasan 'Ali ibn Muhammad Habib al-Bashari al-Baghdadi. t.th. Al-Aḥkām alSulțāniyyah. Beirut: Dar al-Fikr.

Ansary, Tamim. 2009. Destiny Disrupted: A History of the World Through Islamic Eyes. New York: Public Affairs.

Armstrong, Karen. 2005. Jerusalem: One City, Three Faiths. New York: Ballatine Books.

Bar, Gideon. t.t. "Reconstructing the Past: The Creation of Jewish Sacred Space in the State of Israel, 1948-1967." Israel Studies 13(3):1-21.

Basyir, Kunawi. 2016. "Ideologi Gerakan Politik Islam di Indonesia." Al-Tahrir: Jurnal Pemikiran Islam 16(2):267-362.

Belkeziz, Abdelilah. 2009. The State in Contemporary Islamic Thought: A Historical Survey of the Major Muslim Political Thinkers of the Modern Era. London: I.B. Tauris.

Black, Jonanthan. 2013. The Sacred History: How Angels, Mystics and Higher Intelligence Made Our World. London: Quercus.

Bustamam-Ahmad, Kamaruzzaman. 2001. Relasi Islam dan Negara dalam Perspektif Modernisme dan Fundamentalisme. Magelang: Indonesia Tera.

Bustamam-Ahmad, Kamaruzzaman. 2013. Sejarah Islam Politik Indonesia: Dari Pra-Kemerdekaan Hingga Era Reformasi. Banda Aceh: Ar-Raniry Press.

Bustamam-Ahmad, Kamaruzzaman. 2015. From Islamic Revivalism to Islamic Radicalism in Southeast Asia: A Study of Jama'ah Tabligh in Malaysia and Indonesia. Cambridge: Cambride Scholars Publishing.

Bustamam-Ahmad, Kamaruzzaman. 2017a. Acehnologi. Banda Aceh: Bandar Publishing.

Bustamam-Ahmad, Kamaruzzaman. 2017b. Masa Depan Dunia. Banda Aceh: Bandar Publishing.

Chan, Anton. 2015. "The Call of ISIS: The Medium and the Message Attracting Southeast Asians." Counter Terrorist Trends and Analysis 7(4):4-9.

Cottam, Martha L., dan Richard W. Cottam. 2001. Nationalism e Politics: The Political Behaviour of Nation States. Colorado: Lynne Rienner.

Doran, Michael. 2002. "The Pragmatic Fanaticism of al Qaeda: An Anatomy of Extremism in Middl East.” Political Science Quartely 117(2):177-90.

Esposito, John L. 1984. Islam and Politics. Syracuse: Syracuse University Press.

Fisk, Robert. 2006a. The Great War for Civilisation: The Conquest of the Middle East. London: Harper Perennial.

Friedman, George. 2010. The Next 100 Years: A Forecast for the 21st Century. New York: Anchor Books.

Friedman, George. 2012. The Next Decade: Empire and Republic in a Changing World. New York: Anchor Books.

Fukuyama, Francis. 2012. The Origins of Political Order: From Prehuman Times to French Revolution. New York: Farrar, Straus and Giroux.

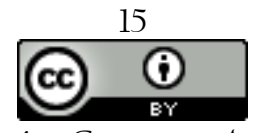

This work is licensed under a Creative Commons Attribution 4.0 International License 


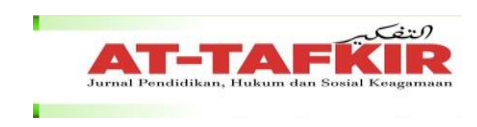

\section{VOLUME 14 NOMOR 1 TAHUN 2021}

P-ISSN : 1979-9357

E-ISSN : 2620-5858

Fuller, Graham E. 2010. A World Without Islam. London: Back Bay Books.

Hallaq, Wael B. 2013. The Impossible State: Islam, Politics, and Modernity Moral Predicament. New York: Columbia University Press.

Hendropriyono, Abdullah Mahmud. 2009. Terorisme, Fundamentalisme Kristen, Yahudi, Islam. Jakarta: Kompas.

Ibn Khaldun. 2001. Mukaddimah. Jakarta: Pustaka Al-Kautsar.

Ismail, Salwa. 2003. Rethinking Islamist Politics: Culture, the State, and Islamism. London: I.B. Tauris.

Kissinger, Henry. 2014. World Order. New York: Penguin Press.

Lewis, Bernard. 1952. "Islamic Revival in Turkey." International Affairs 28(1):38-48.

Lewis, Bernard. 1993. Islam and the West. New York: Oxford University Press.

Lewis, Bernard. 2002. What Went Wrong? The Clash Between Islam and Modernity in the Middle East. New York: Oxford University Press.

Madjid, Nurcholish. 1999. “Kalam Kekhalifahan Manusia dan Reformasi Bumi.” Hlm. 203-65 dalam Cita-Cita Politik Islam Era Reformasi, disunting oleh B. Munawar-Rachman. Jakarta: Paramadina.

Mahbuni, Kishore. 2013. The Great Convergence: Asia, The West, and The Logic of One World. New York: Public Affairs.

Malinowski, Bronislaw. 1941. "An Anthropological Analysis of War.” The American Journal of Sociology 46(4):521-50.

National Intelligence Council. 2004. Mapping the Global Future: Report of the National Intelligence Council's 2020 Project. National Intelligence Council.

Oliver-Dee, Sean. 2009. The Caliphate Question: The British Government and Islamic Governance. New York: Lexington Books.

Purwawidada, Fajar. 2014. Jaringan Baru Teroris Solo. Jakarta: Kompas.

Rahardjo, Dawam. 1996. Ensiklopedi Al-Qur'an: Tafsir Sosial Berdasarkan Konsep-Konsep Kunci. Jakarta: Paramadina.

Roy, Olivier. 1996. Gagalnya Islam Politik. Jakarta: Serambi.

Roy, Olivier. 2004. Globalised Islam: The Search for New Ummah. London: Hurst \& Company.

Satia, Priya. 2008. Spies in Arabia: The Great War and the Cultural of Britain Covert Empire in the Middle East. Oxford: Oxford University Press.

Stern, Jessica, dan J. M. Berger. 2015. ISIS: The State of Terror. Great Britain: William Collins.

6

This work is licensed under a Creative Commons Attribution 4.0 International License 